\title{
Isotopic age dating in Liverpool Land, East Greenland
}

\author{
Bent Tauber Hansen and Johan Ditlev Friderichsen
}

\begin{abstract}
In Liverpool Land in the eastern part of the Scoresby Sund region gneisses and migmatites were intruded by a number of intermediate plutonites and by younger granites. $\mathbf{A}$ number of $\mathrm{K}-\mathrm{Ar}, \mathrm{Rb}-\mathrm{Sr}$ and $\mathrm{U}-\mathrm{Pb}$ isotope age determinations indicate that:

1) the gneisses have a pre-Caledonian as well as a Caledonian history,

2) the migmatites were thoroughly reworked during the late part of the Caledonian orogeny, while

3) the plutonic rocks all seem to have been intruded during the Caledonian orogeny.

B.T. H., Institut für Mineralogie, Westfälische Wilhelms-Universität, Corrensstrasse 24, D-4400 Münster, Western Germany

J. D. F., Grønlands Geologiske Undersøgelse, Øster Voldgade 10, DK-1350, Copenhagen K, Denmark.
\end{abstract}

During the summers of 1969 and 1971 detailed geological investigations were carried out in Liverpool Land in the course of systematic mapping of the Scoresby Sund region by the Geological Survey of Greenland (Coe \& Cheeney, 1972; Henriksen \& Higgins, 1976). The subsequent laboratory work included a programme of $\mathrm{Rb}-\mathrm{Sr}$ isotope age dating studies, which led to ambiguous results ( $\mathrm{O}$. van Breemen, personal communication). This led to increasing emphasis on alternative methods of dating. A limited number of large samples had been collected from suitable rocks for the purpose of $\mathrm{U}-\mathrm{Pb}$ age determinations on zircons, and this paper reports on the results obtained from the zircons and on some other geochronological studies of the Liverpool Land rocks.

\section{Geological setting}

In the Scoresby Sund region the crystalline core of the Caledonian fold belt crops out below younger sediments. Most of the fjord region exposes crystalline rocks influenced to a varying degree by the Caledonian orogeny. A large part of the eastern half of the region is, however, occupied by a major post-Caledonian sedimentary basin (the Jameson Land basin) containing Devonian to Lower Cretaceous non-metamorphosed rocks. Liverpool Land (and Canning Land to its north) represents a horst-like uplift of the crystalline basement at the east side of the Jameson Land basin; various lithological comparisons and correlations with the crystalline areas to the west have been proposed (Coe \& Cheeney, 1972; Henriksen \& Higgins, 1976; Bengaard, 1985; Henriksen, 1985). The present geochronological work is an attempt to clarify the lithological correlations. 


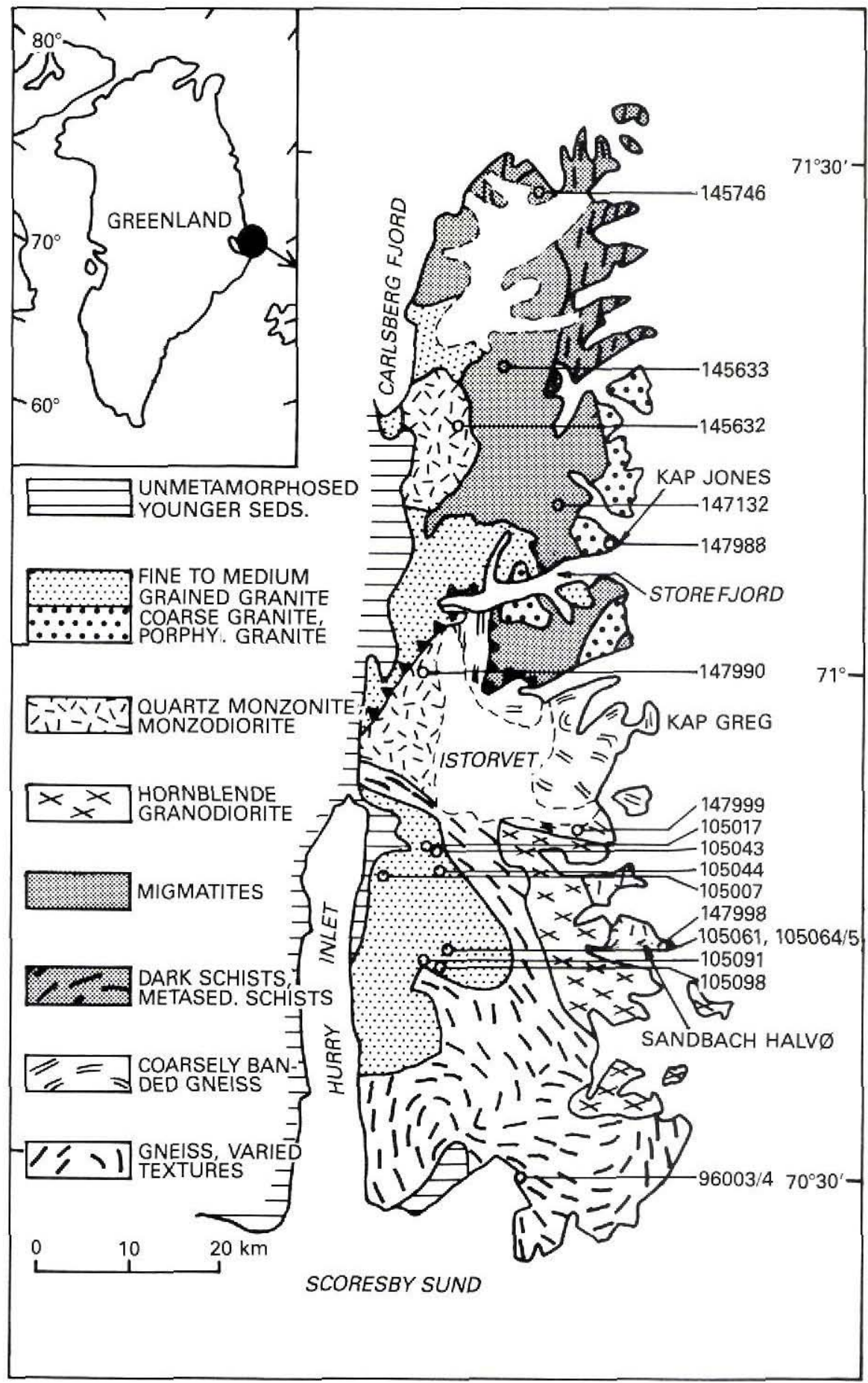

Fig. 1. Geological map of Liverpool Land showing the principal lithological units. Collection sites are indicated by sample numbers. 


\section{Analytical procedures}

All the laboratory work (apart from the K-Ar determinations) was carried out at the Zentrallaboratorium für Geochronologie (ZLG) at the University of Münster, according to the methods described by Persson et al. (1983) for the U-Pb analyses, and Persson \& Hansen (1982) for the Rb-Sr analyses. All ages quoted in this paper have been recalculated using the constants recommended by the IUGS subcommission on geochronology (Steiger \& Jäger, 1977). Errors based on replicate analyses are $0.7 \%$ for ${ }^{207} \mathrm{~Pb} /{ }^{235} \mathrm{U}$, and $0.4 \%$ for ${ }^{206} \mathrm{~Pb} /{ }^{238} \mathrm{U}$ and ${ }^{207} \mathrm{~Pb} /{ }^{206} \mathrm{~Pb}$; for ${ }^{87} \mathrm{Sr} /{ }^{86} \mathrm{Sr}$ and ${ }^{87} \mathrm{Rb} /{ }^{86} \mathrm{Sr}$, errors of $0.05 \%$ and $1.5 \%$ respectively were assigned. Regression lines were calculated according to the least squares method of York (1969). Errors quoted in this paper are $2 \sigma$ of the means.

\section{Liverpool Land gneiss complexes}

The gneisses which occur in the southern two thirds of Liverpool Land are the oldest rock units exposed, and are intersected by abundant bodies of younger plutonic rocks. Two separate gneiss complexes are distinguished.

\section{Southern complex of gneisses with variable textures}

This gneiss complex has been described by Cheeney (1985) and is composed of a series of quartzofeldspathic gneisses (fig. 1). They include strongly sheared basic gneisses of presumed Lower Proterozoic age and an underlying inhomogeneous series of light-coloured gneisses with scattered inclusions of mafic and ultramafic rocks.

Samples $96003 / 4$ (fig. 1, Table 1) were collected from a garnet amphibolite lens in the lower part of the gneiss series. The K-Ar age of $1134 \pm 40 \mathrm{Ma}$ was obtained on hornblende, and is interpreted as the time of the last major recrystallisation.

Sample 105043 (fig. 1, Table 1) represents the hornblende-biotite gneiss forming the country rock to the Hurry Inlet granite (described below); it has been described by Coe \& Cheeney (1972) as a veined garnet-hornblende-biotite gneiss. The K-Ar age of $1193 \pm 40 \mathrm{Ma}$ is interpreted as the minimum age for the event forming this gneiss.

Table 1. K-Ar analytical data for hornblende from gneiss in Liverpool Land

\begin{tabular}{lcccc}
\hline $\begin{array}{l}\text { GGU } \\
\text { Sample No }\end{array}$ & $\begin{array}{c}\text { Potassium } \\
\text { Wt \% }\end{array}$ & $\begin{array}{c}\text { Radiogenic }{ }^{40} \mathrm{Ar} \text { in } \\
10^{-8} \mathrm{cc} / \mathrm{g} \text { (STP) }\end{array}$ & $\begin{array}{ccc}\text { Radiogenic }{ }^{40} \mathrm{Ar} \\
\text { Total }{ }^{40} \mathrm{Ar}\end{array}$ & Age in Ma \\
\hline $96003 / 4$ & 0.268 & 1643 & 0.830 & $1134 \pm 40$ \\
105043 & 0.1657 & 1088 & 0.857 & $1193 \pm 40$ \\
\hline
\end{tabular}

Potassium analyses by atomic absorbtion (R. Heusser, ETH Zürich).

Argon analyses (U. Frick, ETH Zürich). 


\section{The northern complex of coarsely banded gneiss}

This complex in central Liverpool Land has been described by Coe (1975) as having a general domal shape. The complex has tectonic contacts with the surrounding rocks; a Caledonian thrust cuts off the gneissic banding to the north, while to the south a thin, mylonitic garnet-quartz rich gneiss forms the boundary. Coe (1975) made a threefold division of the complex, of which the upper division is the mylonitic gneiss; the middle division comprises concordant amphibolites and paragneiss, heavily injected by granitic veins; the lower division is structurally complex, but of a more homogeneous composition than the middle division. The mylonitisation of the upper division is thought to be Middle Proterozoic (Bengaard, 1985).

Sample 147999 from the coarsely banded gneiss (fig. 1) is a typical representative of the middle division of the complex. The U-Pb data points for four of the zircon fractions (Table 2) define a discordia with a lower intercept at $446+42 \mathrm{Ma}$ (fig. 2). This age seems to reflect metamorphic overprinting during early Caledonian time, and is possibly related to the heavy injection of granitic veins. The data points all indicate the presence of older, inherited components in the zircons.

The upper intercept age of $1880 \mathrm{Ma}$ is somewhat uncertain due to the long extrapolation, but the ${ }^{207} \mathrm{~Pb} /{ }^{206} \mathrm{~Pb}$ ages of all fractions are in the range of 1110 to $1170 \mathrm{Ma}$, which is interpreted as a minimum age for the gneiss formation.

$\mathrm{Rb}$-Sr analyses were carried out on the same samples. The whole rock/biotite tie line (Table 3) corresponds to a $\mathrm{Rb}-\mathrm{Sr}$ age as young as $372 \pm 6 \mathrm{Ma}$, which may be related to late Caledonian veining.

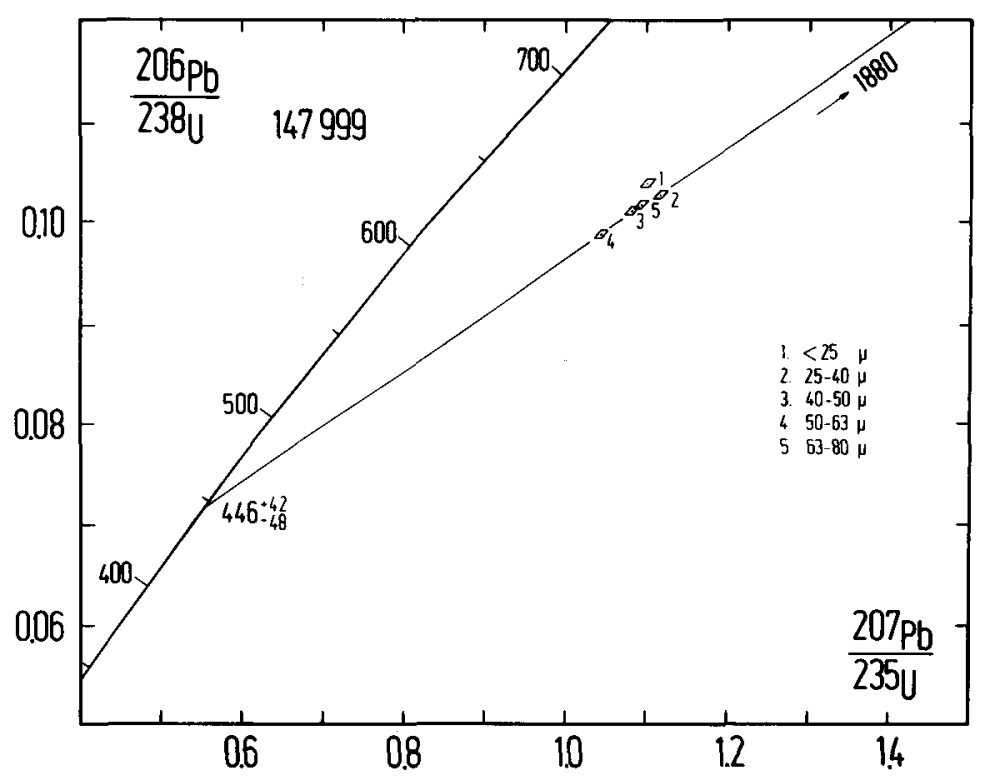

Fig. 2. Concordia plot of the analysed zircon fractions from sample 147999, the coarsely banded gneiss. 
Table 2. U-Pb analytical data for crystalline rocks in Liverpool Land

\begin{tabular}{|c|c|c|c|c|c|c|c|c|c|c|}
\hline \multirow{3}{*}{$\begin{array}{l}\text { GGU sample } \\
\text { No \& sieve } \\
\text { fraction } \\
\text { in } \mu \mathrm{m}^{*}\end{array}$} & \multirow{3}{*}{$\begin{array}{l}\text { g sample } \\
\text { analysed }\end{array}$} & \multicolumn{3}{|c|}{ Observed atomic ratios } & \multirow{3}{*}{$\begin{array}{c}\mathrm{U} \\
\mathrm{ppm}\end{array}$} & \multirow{3}{*}{$\begin{array}{l}\mathrm{Pb}_{\mathrm{rad}} \\
\mathrm{ppm}\end{array}$} & \multirow{3}{*}{$\begin{array}{c}{ }^{206} \mathrm{~Pb}_{\mathrm{rad}} \\
\mathrm{n} \mathrm{mol} / \mathrm{g}\end{array}$} & \multirow{2}{*}{\multicolumn{3}{|c|}{$\begin{array}{l}\text { Atomic ratios corrected for } \\
\text { blank }^{\dagger} \text { and common } \mathrm{Pb}\end{array}$}} \\
\hline & & $208 \mathrm{~Pb}$ & $\stackrel{207}{ } \mathrm{~Pb}$ & $206 \mathrm{~Pb}$ & & & & & & \\
\hline & & & & & & & & $\frac{{ }^{206} \mathrm{~Pb}}{{ }^{238} \mathrm{U}}$ & $\frac{207 \mathrm{~Pb}}{235 \mathrm{U}}$ & $\frac{207 \mathrm{~Pb}}{206 \mathrm{~Pb}}$ \\
\hline \multicolumn{11}{|l|}{$G G U 145632$} \\
\hline$<40 \mathrm{~T}$ & 0.0115 & 0.198673 & 0.060592 & 2568 & 546 & 36.2 & 141.4 & 0.06215 & 0.47039 & 0.05490 \\
\hline $63-80 \mathrm{Cl}$ & 0.0039 & 0.196351 & 0.063982 & 1654 & 392 & 27.1 & 106.6 & 0.06524 & 0.49604 & 0.05514 \\
\hline $80-100 \mathrm{Cl}$ & 0.0070 & 0.192074 & 0.060876 & 2733 & 333 & 26.1 & 102.4 & 0.07379 & 0.57025 & 0.05605 \\
\hline$>100 \mathrm{Cl}$ & 0.0103 & 0.232008 & 0.062281 & 2163 & 387 & 26.9 & 102.5 & 0.06353 & 0.48864 & 0.05578 \\
\hline \multicolumn{11}{|l|}{$G G U 145633$} \\
\hline$<355 \mathrm{Cl}$ & 0.00015 & 0.347072 & 0.166025 & 131 & 478 & 26.7 & 116.1 & 0.05831 & 0.43291 & 0.05385 \\
\hline \multicolumn{11}{|l|}{$G G U 145746$} \\
\hline$<40 \mathrm{~T}$ & 0.0013 & 0.174456 & 0.066660 & 1472 & 518 & 39.3 & 157.8 & 0.07280 & 0.56908 & 0.05669 \\
\hline $40-63 \mathrm{Cl}$ & 0.0007 & 0.196473 & 0.075910 & 766 & 606 & 46.3 & 178.6 & 0.07353 & 0.57594 & 0.05681 \\
\hline $63-80 \mathrm{Cl}$ & 0.0013 & 0.181036 & 0.071236 & 963 & 453 & 34.0 & 137.2 & 0.07261 & 0.56083 & 0.05602 \\
\hline $80-100 \mathrm{Cl}$ & 0.0004 & 0.257728 & 0.107500 & 286 & 436 & 32.2 & 131.2 & 0.07213 & 0.56019 & 0.05632 \\
\hline $100-125 \mathrm{Cl}$ & 0.0006 & 0.191757 & 0.081767 & 579 & 482 & 35.7 & 146.1 & 0.07265 & 0.56544 & 0.05645 \\
\hline \multicolumn{11}{|l|}{ GGU 147132} \\
\hline$<40 \mathrm{~T}$ & 0.0221 & 0.086161 & 0.071911 & 6092 & 738 & 65.5 & 277.9 & 0.08977 & 0.86097 & 0.06956 \\
\hline $40-63 T$ & 0.0101 & 0.081830 & 0.075750 & 7703 & 661 & 66.5 & 280.3 & 0.10164 & 1.0355 & 0.07389 \\
\hline $63-100 T$ & 0.0053 & 0.080104 & 0.078553 & 6553 & 812 & 88.0 & 370.8 & 0.10957 & 1.1539 & 0.07638 \\
\hline$<100 \mathrm{~T}$ & 0.0121 & 0.074775 & 0.076139 & 5667 & 722 & 73.7 & 312.9 & 0.10393 & 1.0548 & 0.07362 \\
\hline \multicolumn{11}{|l|}{ GGU 147998} \\
\hline$<25 \mathrm{~T}$ & 0.0107 & 0.308220 & 0.065754 & 1661 & 266 & 20.8 & 75.0 & 0.06758 & 0.53083 & 0.05697 \\
\hline $40-50 \mathrm{~T}$ & 0.0154 & 0.302385 & 0.065975 & 1264 & 231 & 17.9 & 64.9 & 0.06726 & 0.51039 & 0.05504 \\
\hline $63-80 T$ & 0.0164 & 0.291505 & 0.065796 & 1299 & 242 & 18.7 & 68.5 & 0.06776 & 0.51004 & 0.05459 \\
\hline $80-100 \mathrm{~T}$ & 0.0257 & 0.288386 & 0.065591 & 1387 & 234 & 18.1 & 66.3 & 0.06796 & 0.51581 & 0.05505 \\
\hline $125-200 \mathrm{~T}$ & 0.0103 & 0.285344 & 0.067820 & 1279 & 226 & 17.3 & 63.6 & 0.06756 & 0.52538 & 0.05640 \\
\hline \multicolumn{11}{|l|}{ GGU 147999} \\
\hline$<25 \mathrm{~T}$ & 0.0095 & 0.115197 & 0.081101 & 3401 & 940 & 99.2 & 407.0 & 0.10380 & & 0.07695 \\
\hline $25-40 T$ & 0.0115 & 0.145118 & 0.094268 & 920 & 1012 & 105.9 & 433.3 & 0.10267 & 1.1155 & 0.07879 \\
\hline $40-50 \mathrm{~T}$ & 0.0114 & 0.114552 & 0.082399 & 2857 & 1036 & 106.3 & 436.6 & 0.10108 & 1.0796 & 0.07746 \\
\hline $50-63 \mathrm{~T}$ & 0.0109 & 0.120401 & 0.084040 & 1387 & 1043 & 104.4 & 429.4 & 0.09870 & 1.0420 & 0.07657 \\
\hline $63-80 T$ & 0.0039 & 0.141585 & 0.090779 & 1093 & 1016 & 105.6 & 430.9 & 0.10169 & 1.0917 & 0.07786 \\
\hline \multicolumn{11}{|l|}{$G G U 147988$} \\
\hline$<25 \mathrm{~T}$ & 0.0071 & 0.143255 & 0.060881 & 2597 & 1255 & 80.6 & 329.8 & 0.06298 & 0.47980 & 0.05525 \\
\hline $25-40 T$ & 0.0142 & 0.142636 & 0.060583 & 2778 & 1321 & 84.9 & 347.1 & 0.06302 & 0.48073 & 0.05533 \\
\hline $40-50 \mathrm{~T}$ & 0.0089 & 0.147701 & 0.063120 & 1942 & 1325 & 81.6 & 334.0 & 0.06046 & 0.46346 & 0.05560 \\
\hline $50-63 T$ & 0.0113 & 0.149229 & 0.061764 & 2304 & 1319 & 84.6 & 345.4 & 0.06271 & 0.47926 & 0.05543 \\
\hline $63-80 T$ & 0.0038 & 0.166568 & 0.066251 & 1563 & 1235 & 79.8 & 322.1 & 0.06255 & 0.49089 & 0.05692 \\
\hline \multicolumn{11}{|l|}{ GGU 147990} \\
\hline$<25 \mathrm{~T}$ & 0.0065 & 0.319052 & 0.063724 & 1789 & 344 & 26.9 & 96.1 & 0.06705 & 0.51350 & 0.05555 \\
\hline $40-50 \mathrm{~T}$ & 0.0269 & 0.299130 & 0.060323 & 2890 & 329 & 25.6 & 92.5 & 0.06732 & 0.51306 & 0.05527 \\
\hline $80-100 \mathrm{~T}$ & 0.0057 & 0.304409 & 0.070390 & 939 & 289 & 22.1 & 80.7 & 0.06697 & 0.50656 & 0.05486 \\
\hline
\end{tabular}

* $\mathrm{T}=$ Total fraction, $\mathrm{Cl}=$ Clear idiomorphic fraction.

$\dagger$ Composition of lead used for blank correction ${ }^{206} \mathrm{~Pb} /{ }^{204} \mathrm{~Pb}=18.7,{ }^{207} \mathrm{~Pb} /{ }^{204} \mathrm{~Pb}=15.63$, ${ }^{208} \mathrm{~Pb} /{ }^{204} \mathrm{~Pb}=38.63$.

The composition of common lead used for correction accords to the model of Stacey \& Kramers (1975). 


\section{Migmatites and schists}

The northern part of Liverpool Land is dominated by metasedimentary rocks in the north and extensive areas of migmatites in the central part (fig. 1).

Sample 145746 comes from the northern area of metasedimentary rocks, but represents a body of metamorphosed and foliated granodiorite. The sample has been dated by the U-Pb method on zircons. For the fractions coarser than $40 \mu$ only clear idiomorphic grains were analysed, in order to date the last time of growth of new zircon grains, whereas the fraction finer than $40 \mu$ is a total fraction (Table 2). All five data points plot nearly concordantly and indicate an age of $445+12 \mathrm{Ma}$ (fig. 3) for the last important metamorphic recrystallisation.

Due to the long extrapolation the upper intercept age of some $1200 \mathrm{Ma}$ is poorly defined.

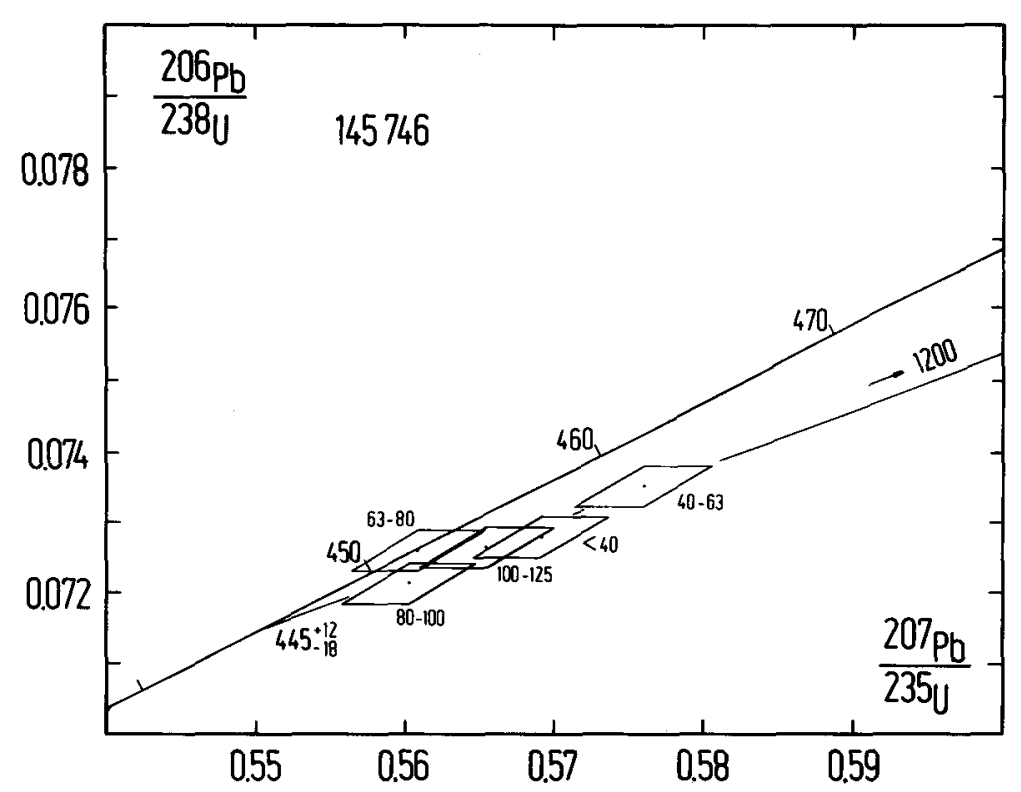

Fig. 3. Concordia plot of the analysed zircon fractions from sample 145746, a metagranodiorite from the migmatite area.

Sample 147132 is from an acid vein in the southern part of the extensive migmatite area (fig. 1). Five size fractions of zircons were analysed from this sample (fig. 4, Table 2). The data indicate that a considerable amount of inherited material is present with a minimum age of $1100 \mathrm{Ma}$. The inherited material is probably also responsible for the scatter of the data points around the best fit line. The lower intercept age of $396 \pm 16 \mathrm{Ma}$ is regarded as the time of formation of the vein.

Sample 145633 also comes from an acid vein in the migmatite area (fig. 1). One analysis of idiomorphic zircons was undertaken, and the data point (fig. 5, Table 2) shows a concordant age of only $365 \pm 3 \mathrm{Ma}$.

Both samples from veins in the migmatite area give surprisingly young ages, but similar ages 


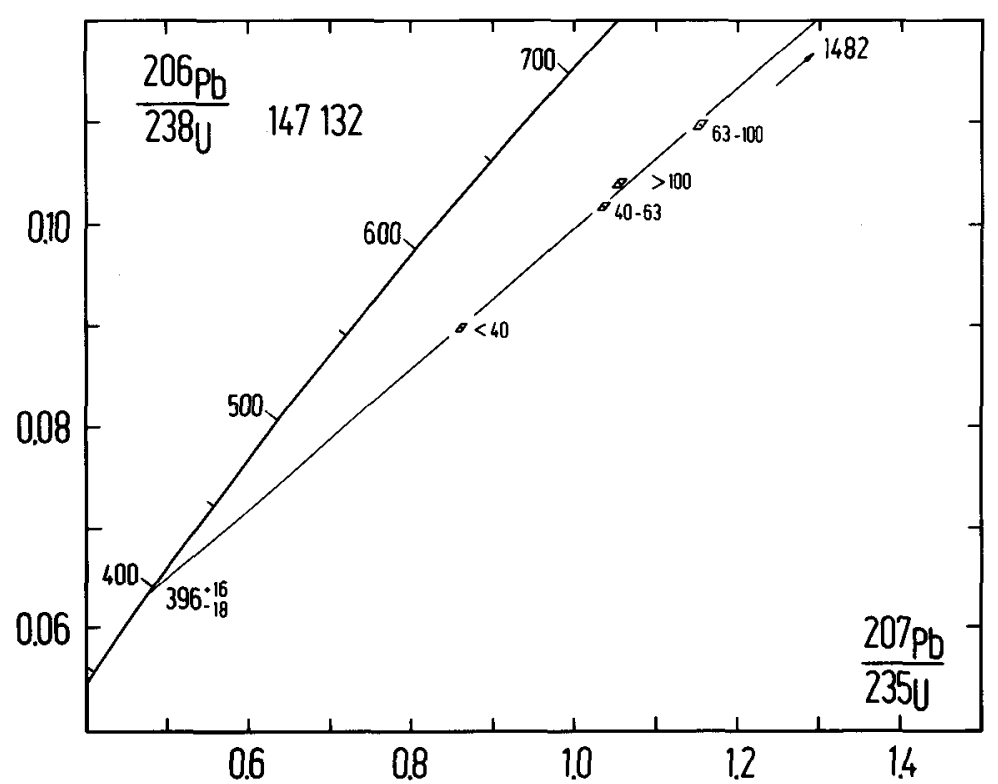

Fig. 4. Concordia plot of the analysed zircon fractions from sample 147132, an acid vein from the migmatite area.

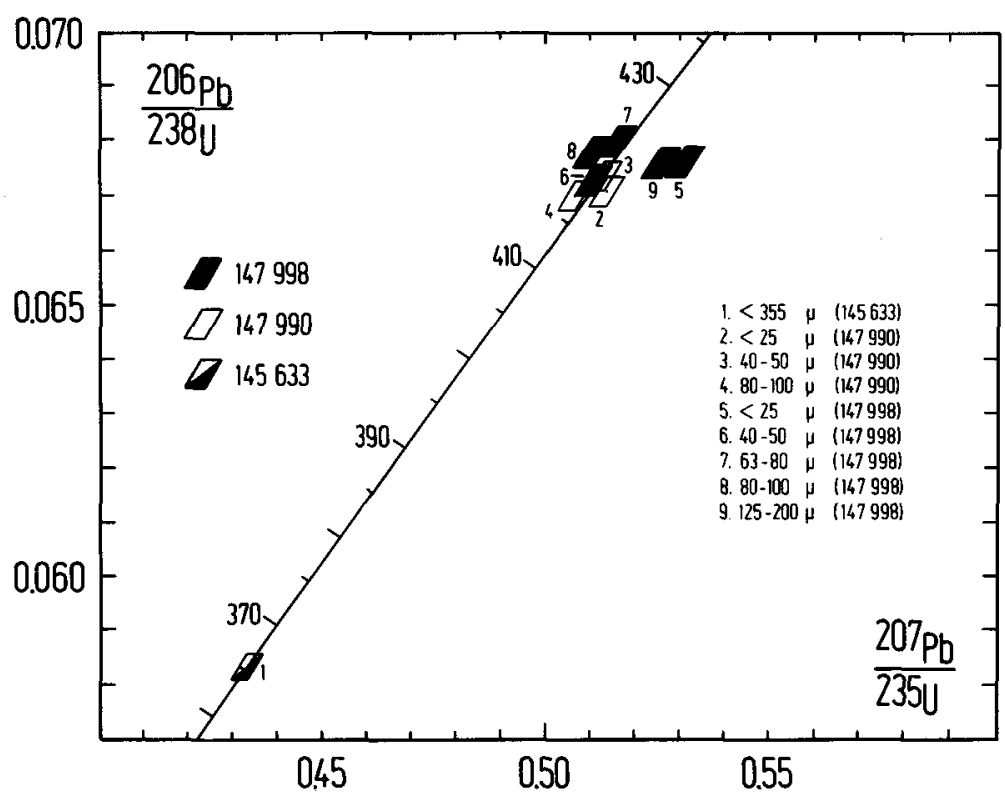

Fig. 5. Concordia plot of the analysed zircon fractions from sample 147998, the Sandbach Halvo hornblende-quartz monzonite; sample 147990, the Istorvet hornblende-quartz monzonite and sample 145633 , an acid vein from the migmatite area. 
have been reported from immediately west of the post-Caledonian sedimentary basin, namely from the youngest plutonic rocks and from veins in the migmatite (Hansen \& Tembusch, 1979; Hansen et al., 1987).

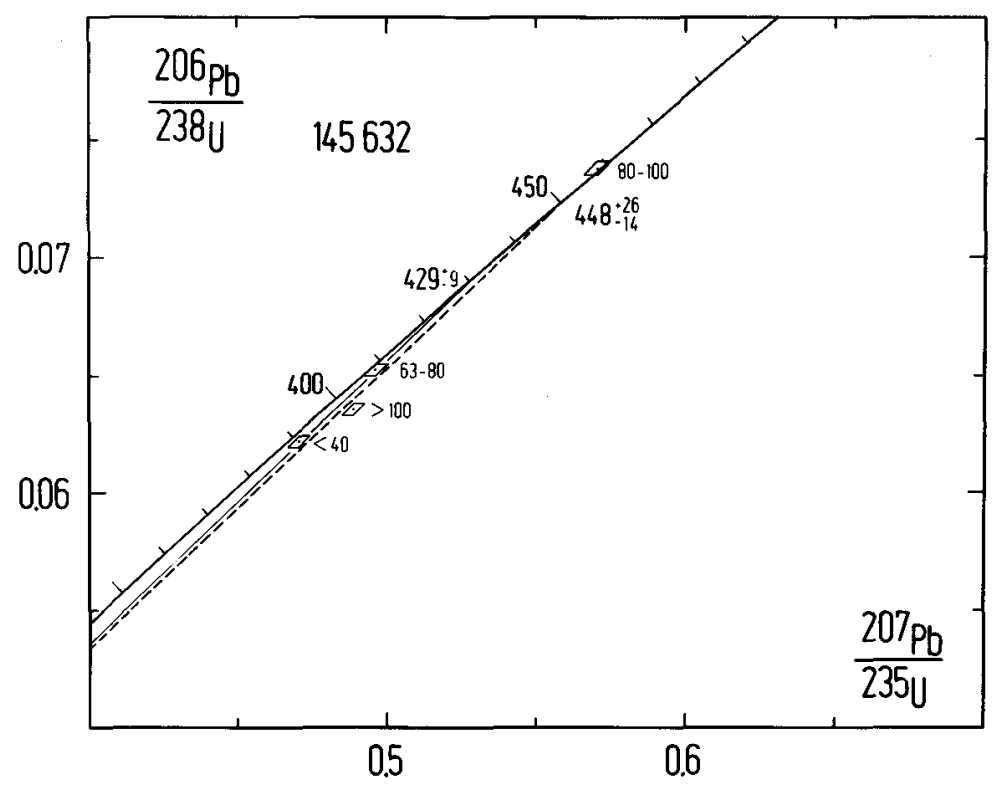

Fig. 6. Concordia plot of the analysed zircon fractions from sample 145632, the hornblende-biotitequartz monzonite at Carlsberg Fjord.

\section{Plutonic rocks in Liverpool Land}

A suite of intrusions post-date the metamorphic rocks. Among the intrusive rocks quartz monzonites are thought to be older than a series of granites.

\section{Quartz monzonites}

Sample 147998 represents a massive hornblende-quartz monzonite body on Sandbach Halvø (fig. 1). It has a slight foliation parallel to the margin, and contains a few dioritic inclusions. Five fractions of zircons yielded a concordant Caledonian age of close to $420 \mathrm{Ma}$ (fig. 5, Table 2). Rb-Sr analyses have been carried out on the same sample (Table 3), and a whole rock-biotite tie line age of $398 \pm 9 \mathrm{Ma}$ was obtained.

Sample 147990 is also derived from a massive hornblende-quartz monzonite situated just west of Istorvet. This slightly foliated rock cuts across the mylonitic gneiss to the south, but is cut by a Caledonian thrust to the north. Three fractions of zircon were analysed and gave a concordant U-Pb age close to $420 \mathrm{Ma}$, the same as sample 147998 (fig. 5, Table 2). Rb-Sr analyses were also undertaken on this sample, but the biotite from the sample is slightly chloritised, and some associated loss of radiogenic ${ }^{87} \mathrm{Sr}$ seems to have decreased the age to 357 $\pm 13 \mathrm{Ma}$ (Table 3). 
Sample 145632 comes from a hornblende-biotite-quartz monzonite east of the head of Carlsberg Fjord. The monzonite displays irregular contacts with the surrounding rocks. U-Pb isotope determinations were made on four zircon fractions, and these have a complicated plot pattern (fig. 6, Table 2). The points define a chord with an upper intercept of $448+26 \mathrm{Ma}$, while the lower intercept lies close to zero, indicating a recent loss of lead and disturbance of the U-Pb system. Such patterns have previously been observed in plutonic rocks from Liverpool Land (Hansen \& Friderichsen, unpublished). The presence of inherited material may be neglected in the two fine fractions, where an age of $429 \pm 9$ Ma is observed.

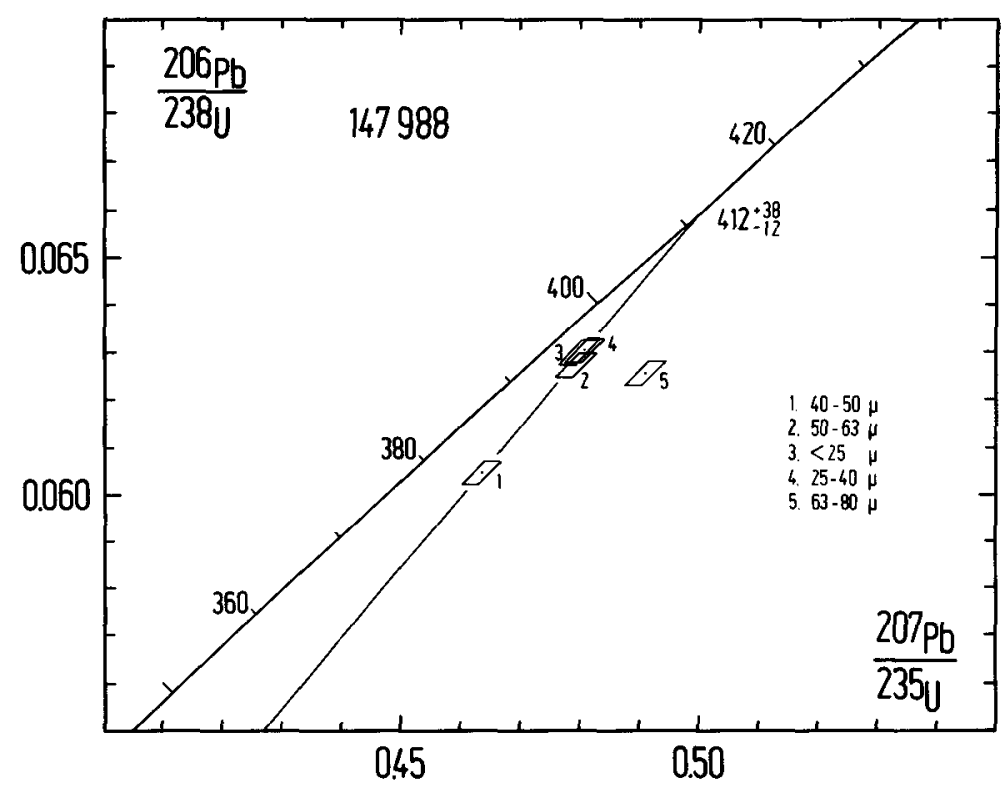

Fig. 7. Concordia plot of the analysed zircon fractions from sample 147988, the Kap Jones granite.

\section{Granites}

The intrusion of a suite of granite bodies marked the end of the plutonic regime in Liverpool Land. Field relationships indicate that they originated within a single plutonic episode.

\section{The Kap Jones granite}

Sample 147988 was collected at Kap Jones from the medium to coarse grained hornblende granite which contains numerous migmatite host rock inclusions. Feldspar phenocrysts are up to $10 \mathrm{~cm}$ long. U-Pb isotope analyses were carried out on five zircon fractions, of which four define a discordia with an upper intercept at $412+{ }_{-12}^{38} \mathrm{Ma}$ (fig. 7, Table 2). This age is interpreted as the time of intrusion. The fifth and coarsest fraction (63 to $80 \mu \mathrm{m}$ ) clearly reflects the presence of older inherited material. The slight discordance of all the data points can be referred to recent loss of lead. A Rb-Sr whole rock/biotite age determination gave $402 \pm 5$ Ma (Table 3). 
Table 3. $\mathrm{Rb}$-Sr analytical data from intrusive rocks in Liverpool Land

\begin{tabular}{|c|c|c|c|c|c|c|c|c|}
\hline $\begin{array}{l}\text { GGU } \\
\text { Sample No }\end{array}$ & $\begin{array}{r}\text { Type of } \\
\text { sample * }\end{array}$ & $\begin{array}{c}\mathrm{Rb} \\
\mathrm{ppm}\end{array}$ & $\begin{array}{c}\mathrm{Sr} \\
\mathrm{ppm}\end{array}$ & $\begin{array}{c}{ }^{86} \mathrm{Sr} \\
\mu \mathrm{mol} / \mathrm{g}\end{array}$ & $\frac{{ }^{87} \mathrm{Rb}}{{ }^{86} \mathrm{Sr}}$ & $\frac{{ }^{87} \mathrm{Srt}}{{ }^{86 \mathrm{Sr}}}$ & $\begin{array}{l}\text { Age } \\
\mathrm{Ma}\end{array}$ & $\frac{{ }^{87} \mathrm{Sr}}{{ }^{86} \mathrm{Sr}_{0}}$ \\
\hline 105007 & WR & 93.6 & 1679 & 1.889 & 0.161 & 0.71084 & \multirow{5}{*}{$438 \pm 42$} & \multirow{5}{*}{$0.7096 \pm 0.0003$} \\
\hline 105017 & WR & 68.7 & 1360 & 1.531 & 0.146 & 0.71066 & & \\
\hline 105061 & WR & 114.4 & 453 & 0.5101 & 0.730 & 0.71407 & & \\
\hline 105065 & WR & 125.2 & 489 & 0.5505 & 0.741 & 0.71470 & & \\
\hline 105098 & WR & 113.4 & 783 & 0.8811 & 0.419 & 0.71183 & & \\
\hline 105064 & WR & 102.3 & 594 & 0.6685 & 0.499 & 0.71248 & \multirow{4}{*}{$425 \pm 7$} & \multirow{4}{*}{$0.7095 \pm 0.0005$} \\
\hline 105064 & $\mathrm{Bi}$ & 518.8 & 17.5 & 0.0186 & 90.49 & 1.2567 & & \\
\hline 105044 & WR & 101.7 & 434 & 0.4878 & 0.679 & 0.71248 & & \\
\hline 105091 & WR & 108.7 & 526 & 0.5917 & 0.598 & 0.71432 & & \\
\hline $\begin{array}{l}147988 \\
147988\end{array}$ & $\begin{array}{c}\text { WR } \\
\text { Bi }\end{array}$ & $\begin{array}{l}135.3 \\
805.5\end{array}$ & $\begin{array}{l}715 \\
29.5\end{array}$ & $\begin{array}{l}0.8050 \\
0.0317\end{array}$ & $\begin{array}{l}0.547 \\
82.7\end{array}$ & $\left.\begin{array}{l}0.71036 \\
1.1788\end{array}\right\}$ & $402 \pm 5$ & $0.7072 \pm 0.0005$ \\
\hline 147990 & WR & 51.0 & 1743 & 1.962 & 0.085 & 0.70790 & \multirow{2}{*}{$357 \pm 13$} & \multirow{2}{*}{$0.7075 \pm 0.0004$} \\
\hline 147990 & $\mathrm{Bi}$ & 247.5 & 94.0 & 0.1055 & 7.64 & 0.74635 & & \\
\hline 147998 & $\mathrm{Wr}$ & 68.0 & 1605 & 1.807 & 0.122 & 0.70823 & \multirow{2}{*}{$398 \pm 9$} & \multirow{2}{*}{$0.7075 \pm 0.0004$} \\
\hline 147998 & $\mathrm{Bi}$ & 290.0 & 44.3 & 0.0494 & 19.1 & 0.81585 & & \\
\hline 147999 & WR & 179.9 & 158.6 & 0.1773 & 3.31 & 0.78025 & \multirow{2}{*}{$372 \pm 6$} & \multirow{2}{*}{$0.7627 \pm 0.0009$} \\
\hline 147999 & $\mathrm{Bi}$ & 1110.0 & 7.03 & 0.0060 & 601.0 & 3.9448 & & \\
\hline
\end{tabular}

* $\mathrm{Bi}=$ biotite, $\mathrm{WR}=$ whole rock

$\dagger{ }^{87} \mathrm{Sr} /{ }^{86} \mathrm{Sr}$ normalized to ${ }^{86} \mathrm{Sr} /{ }^{88} \mathrm{Sr}$ of 0.1194

\section{The Hurry Inlet granite}

This is the largest intrusive rock body in Liverpool Land. The granite has been described by Kranck (1935) and Coe (1975) as a uniform, pink and medium grained biotite granite.

Sample 105064 (fig. 1) was subjected to $\mathrm{Rb}-\mathrm{Sr}$ analyses on biotite reported by Hansen \& Steiger (1971). They record a $\mathrm{Rb}-\mathrm{Sr}$ biotite age of $434 \mathrm{Ma}$, for which the analytical data (previously unpublished) are presented in Table 3 in this paper.

Samples 105007, 105017, 105044, 105061, 105064, 105065, 105091 and 105098 (fig. 1) were employed in the present study for a number of additional $\mathrm{Rb}-\mathrm{Sr}$ whole rock age determinations on different facies of the Hurry Inlet granite (fig. 8, Table 3). Of the eight samples analysed, two (samples 105044 and 105091) were omitted in the calculation of the best fit line. The isochron obtained (with MSWD: 0.99) gives an age of $438 \pm 42 \mathrm{Ma}$ for the intrusion of the Hurry Inlet granite. For the same granite Gleadow \& Brooks (1979) obtained a fission track uplift age on sphene of $410 \pm 10 \mathrm{Ma}$.

The omission of the two samples can be justified on geological reasons. Sample 105044 was taken from close to a thick unit of siliceous garnet-biotite gneiss, a major Proterozoic shear zone, regenerated in Caledonian time, which may have caused loss of radiogenic ${ }^{87} \mathrm{Sr}$. Sample 105091 was taken from the boundary with the country rock, and the granite here contains thick sheets of a dark and relatively quartz-poor variety of hybrid granite. The position of the data point above the isochron (fig. 8) may therefore be related to contamination with the 


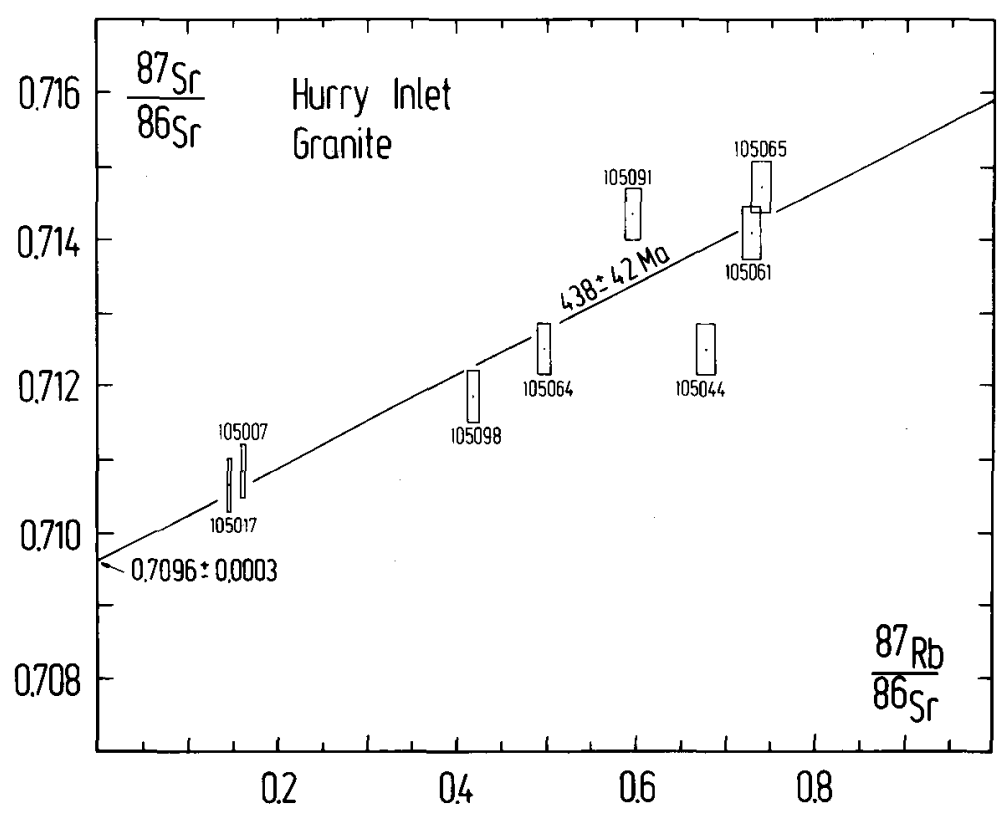

Fig. 8. Rb-Sr isochron diagram for the whole rock samples from the Hurry Inlet granite.

country rock. A whole rock - biotite tieline uplift age of $425 \pm 7 \mathrm{Ma}$ has been calculated for sample 105064 (Table 3).

\section{Conclusions}

This isotopic study demonstrates a distinct difference in the rocks of Liverpool Land, between a southern part dominated by gneissic host rocks and a northern part dominated by migmatites and schists; the two areas are separated by a Caledonian thrust. In the southern part there is $\mathrm{K}-\mathrm{Ar}$ as well as U-Pb isotope evidence for Middle Proterozoic recrystallisation, whereas in the northern area ages are mainly Caledonian, and only inherited material in zircons of sample 147132 indicates the presence of pre-Caledonian rocks.

Adjacent to the western side of the post-Caledonian sedimentary basin there are extensive areas of migmatite which have suffered an intense Caledonian metamorphic overprint (Chadwick, 1975). The paragenesis sillimanite - K-feldspar with (Caledonian) cordierite in that area is also recorded in the northern area of migmatites in Liverpool Land. Caledonian low pressure granulite facies regional metamorphism seems to have affected the crystalline rocks on both sides of the Jameson Land basin in the Upper Ordovician.

The intrusive rocks all give Caledonian ages. The intrusive rocks occur on both sides of the thrust in Liverpool Land and are older than the thrusting. The monzonitic plutonites were emplaced as sheet like bodies and had a marginal foliation produced during their crystallisation; the granites were intruded slightly later, but both types of plutonites were formed within Silurian time (440 to $410 \mathrm{Ma}$ ).

The young ages obtained from veins from both sides of the thrust in Liverpool Land have their counterparts in the region immediately west of the Jameson Land basin; here Hansen et 
al. (1987) report similar ages from late veins. The thrusting in Liverpool Land may have occurred in the Lower Devonian about 400 Ma ago.

The uplift and cooling history of Liverpool Land seems to reflect generation of the granites relatively deep in the crust, such that cooling temperatures of some $350^{\circ} \mathrm{C}$ for the $\mathrm{Rb}-\mathrm{Sr}$ system in biotites were reached some 10 to $20 \mathrm{Ma}$ after their crystallisation. Cooling of the crystalline rocks to below $100^{\circ} \mathrm{C}$ took place as late as the Lower Jurassic, i.e. more than 200 Ma later (Gleadow \& Brooks, 1979). New fission track dating by Hansen (1985) has confirmed the slow uplift of Liverpool Land; this may be compared to that of the crystalline rocks on the west side of the Jameson Land basin, where plutonic activity has been recorded as late as $370 \mathrm{Ma}$ ago (Hansen \& Tembusch, 1979; Hansen et al., 1987).

\section{Acknowledgements}

The samples analysed in this study were collected by R. F. Cheeney, K. Coe, A. K. Higgins and N. Henriksen, and these colleagues also supplied valuable support and information during the work. $O$. van Breemen kindly let us have access to his preparations and unpublished results. One of us (BTH) was supported by Deutsche Forschungsgemeinschaft through grant no. Ha 1166/3-2. We are grateful to H.-J. Bengaard for suggestions, and to A. K. Higgins for critical reading and constructive suggestions of the manuscript.

\section{References}

Bengaard, H.-J. 1985: Beskrivelse til et geologisk, et metamorft og et strukturelt kort i målestokken 1:1.000.000 over Østgrønland $70^{\circ}-82^{\circ} \mathrm{N}$. Unpublished thesis, Copenhagen University, Denmark. $150 \mathrm{pp}$.

Chadwick, B. 1975: The structure of south Renland, Scoresby Sund - with special reference to the tectono-metamorphic evolution of a southern internal part of the Caledonides of East Greenland. Bull. Grønlands geol. Unders. 112, $67 \mathrm{pp}$.

Cheeney, R. F. 1985: The plutonic igneous and high-grade metamorphic rocks of southern Liverpool Land, central East Greenland, part of a supposed Caledonian and Precambrian complex. Rapp. Grønlands geol. Unders. 123, 39 pp.

Coe, K. 1975: The Hurry Inlet granite and related rocks of Liverpool Land. Bull. Granlands geol. Unders. 115, $34 \mathrm{pp}$.

Coe, K. \& Cheeney, R. F. 1972: Preliminary results of mapping in Liverpool Land, East Greenland. Rapp. Gronlands geol. Unders. 48, 7-20.

Gleadow, A. J. W. \& Brooks, C. K. 1979: Fission track dating, thermal histories and tectonics of igneous intrusions in East Greenland. Contr. Miner. Petrol. 71, 45-60.

Hansen, B. T. \& Friderichsen, J. D. (unpublished): The influence of recent lead loss on the interpretation of disturbed U-Pb systems in zircons. Part I: Igneous rocks.

Hansen, B. T. \& Steiger, R. H. 1971: The geochronology of the Scoresby Sund area. Progress report I: $\mathrm{Rb} / \mathrm{Sr}$ mineral ages. Rapp. Gronlands geol. Unders. 37, 55- 57.

Hansen, B. T. \& Tembusch, H. 1979: Rb-Sr isochron ages from east Milne Land, Scoresby Sund, East Greenland. Rapp. Gronlands geol. Unders. 95, 96-101.

Hansen, B. T., Steiger, R. H., Henriksen, N. \& Borchardt, B. 1987: U-Pb and Rb-Sr age determinations on Caledonian plutonic rocks in the central part of the Scoresby Sund region, East Greenland. Rapp. Grenlands geol. Unders. 134, 5-18.

Hansen, K. 1985: Fission track age determinations of vertical movements in the crust caused by continental rifting: a fission track study of the Scoresby Sund area; method and results. Unpublished thesis, Copenhagen University, $119 \mathrm{pp}$.

Henriksen, N. 1985: The Caledonides of central East Greenland $70^{\circ}-76^{\circ} \mathrm{N}$. In Gee, D. G. \& 
Sturt, B. A. (edit.) The Caledonide orogen - Scandinavia and related areas, 1095-1113. John Wiley \& Sons.

Henriksen, N. \& Higgins, A. K. 1976: East Greenland Caledonian fold belt. In Escher, A. \& Watt, W. S. (edit.) Geology of Greenland. The Geological Survey of Greenland, $183-246$.

Kranck, E. H. 1935: On the crystalline complex of Liverpool Land. Meddr Gronland 95(7), 122 pp.

Persson, P. O. \& Hansen, B. T. 1982: The Rb-Sr age of the Sundsta granite in the Western Pregothian tectonic mega-unit, south-western Sweden. Geol. Fören. Stockh. Förh. 104, 17-21.

Persson, P. O., Wahlgren, C. H. \& Hansen, B. T. 1983: U-Pb ages of Proterozoic metaplutonics in the gneiss complex of southern Wärmland, south-western Sweden. Geol. Fören. Stockh. Förh. 105, 1-8.

Stacey, J. S. \& Kramers, J. D. 1975: Approximation of terrestrial lead isotope evolution by a two-stage model. Earth Planet. Sci. Lett. 26, 207-221.

Steiger, R. H. \& Jäger, E. 1977: Subcommission on Geochronology. Convention on use of decay constants in geo- and cosmo-chronology. Earth planet. Sci. Lett. 36, 359-362.

York, D. 1969: Least square fitting of a straight line with correlated errors. Earth Planet. Sci. Lett. 5, $320-324$. 